\title{
Why some Pharmacists Make the Leap and Others do not "From Good to Great Pharmacists"
}

\author{
Rasha Abdelsalam Elshenawy ${ }^{1, *}$, Fatma-elzahraa Ahmed Mahmoud ${ }^{2}$ \\ ${ }^{1}$ Department of Clinical and Pharmaceutical Sciences, University of Hertfordshire, Director of Clinical Pharmacy Practice \\ Programs, FADIC School of Antimicrobial Stewardship, UNITED KINGDOM, WD19 6LN. \\ ${ }^{2}$ Central Administration of Pharmaceutical Affairs, EGYPT.
}

Received: 05 May 2021;

Accepted: 15 July 2021

*Correspondence to:

Dr. Rasha Abdelsalam Elshenawy, BSc. Pharm, MSc. Clin Pharm, BCPS (AQ-ID), Department of Clinical and Pharmaceutical Sciences, University of Hertfordshire, Director of Clinical pharmacy Practice Programs,

FADIC School of Antimicrobial Stewardship, UNITED KINGDOM, WD19 6LN.

Phone no: +447827711871

Email: Rasha.Abdelsalam@FADIC.net, Dra21sha@gmail.com

Copyright: (c) the author(s),publisher and licensee Indian Academy of Pharmacists. This is an open-access article distributed under the terms of the Creative Commons Attribution Non-Commercial License, which permits unrestricted non-commercial use, distribution, and reproduction in any medium, provided the original work is properly cited.

\begin{abstract}
Purpose: The purpose of this study is to define the requirements needed to be an Ideal pharmacist, in addition to determining the best traits that characterize the ideal pharmacist, whichcan help in explaining the quality indicators for leadership practicing. Methods: This is a descriptive study that was carried out through an online Google Drive survey, in the form of a questionnaire, to assess the skills needed by pharmacists. The data collection tool website was available mid- December 2019 through first February 2020. Descriptive statistics were used to report results. Results: Survey respondents were 905 pharmacists from different countries such as Egypt (384), UAE (75), KSA (326), etc. from different specialties. The most important traits of the great pharmacist as reported by the respondents was the ability of an ideal pharmacist to manage and discuss mistakes and to solve any medical problems. The most important reported skills includedthe skills of analytical, computer, communication, leadership, management, mentorship, medical research, and clinical practice. Another finding from the survey is related to the preferred expertise to be specialized. Moreover, continuing medical education (CME) programs can play an essential role in enhancing therapeutic and leadership skills. Conclusion: The terms and definitions for great leader may change with the times; however, it is important to understand the skills and abilities needed to lead. The ability to lead effectively is based on several skills, including communication, managing, and solving mistakes, clinical practicing, and integrity.
\end{abstract}

Key words: Effectiveness, Continuous Education, Leadership, Management Skills, Pharmacy.

\section{INTRODUCTION}

In a perfect medical world, the ideal pharmacist would have different qualifications to lead and have an effective role in pharmacy field. This role is due to changes in health care field, including health information technology and the quality concepts implementation in health care. The responsibilities of pharmacists show greater involvement in patient care and disease state management as well. ${ }^{[1]}$ Bridging the gap between the ideal and the current state of pharmacy practice demands leadership within the profession..$^{[2]}$ Thus, leadership is needed to assure essential non-clinical competencies. ${ }^{[3]}$ The objectives of this study are to define the requirements needed to be an ideal pharmacist and determine the educational qualifications and years of experience from other pharmacist point of view.

\section{METHODS}

Study setting

This cross-sectional survey study was carried out through an online questionnaire on Google Drive. Data were collected in the response sheet and were all password protected by the primary investigator throughout the entirety of the study till its completion.

\section{Data collection}

The study questionnaire was designed to assess the needed skills as communication, analytical, managerial, computer and medical research skills, in addition to the optimal age and clinical practice. Respondents were anonymous, and individual responses were not linked to the source. At initiation of this survey research, 30 original questions (i.e., multiple choice, 5-point Likert scale, preference rank, and open questions) were designed to meet the study objectives. The investigators selected the appropriate format for a specific question. During survey design, questions were assessed for purpose, validity, and clarity and adopted only if they were reliable. When warranted, skip logic was inserted based on the response to pilot questions. Before respondents were recruited, fifty pharmacists serving in different pharmacy practice positions pretested the questions. Following completion of the pilot survey, questions were assessed for validity and reliability using SPSS program. Concurrently, the survey tool was assessed for length, flow, and ease of administration. Questions were modified when necessary. The final questionnaire included 31 items and collected information about the respondent's demographics (e.g., age, gender), pharmacy practice pathway (e.g., years since licensure, current pharmacy position, practice location, years in current position), pharmacist training years, and perception of the most valuable skill sets needed for the great pharmacists. This information also included an evaluation of the pharmacist's preparedness from his or her chosen career path, pharmacists' opinions on the skills of management, leadership, mentorship, communications and expected years of experience.

To investigate the possibility of non-response bias, the first $25 \%$ of responses received were compared with the last 25\%. In February 2020, the link to the survey was e-mailed to pharmacists subscribing to FADIC's Pharmacy Practice list server. At the time of recruitment, there were 1500 subscribers 
to the list server. It is unknown how many pharmacists opted to receive e-mail announcements during the recruitment phase. In an introductory e-mail, recipients were encouraged to complete the questionnaire. A reminder e-mail containing a link to the website was forwarded two weeks later. E-mail recipients were advised to ignore the reminder if they had already completed the questionnaire. The data collection tool website was available mid-December 2019 through first-February 2020. The primary investigator was responsible for downloading and organizing questionnaire responses.

\section{Statistical analysis}

Statistical analysis was performed using Statistical Package for Social Sciences (SPSS) for Windows, version 25. ${ }^{[4]}$ For quantitative data, the Shapiro-Wilk test for normality was performed. Data that did not follow normal distribution were summarized as the median, interquartile range (IQR: expressed as $25^{\text {th }}-75^{\text {th }}$ percentiles), and range. Qualitative variables were summarized as frequencies and percentages.

\section{RESULTS}

The survey respondents were 905 pharmacists from the following countries: Egypt (42.2\%), Saudi Arabia (36\%), United Arab Emirates (8.3\%), Qatar $(2.2 \%)$, Jordan (1.7\%), Iraq (1.7\%), Sudan (1.1\%), Kuwait $(1.1 \%)$, as well as other Arab and non-Arab countries. The study included 330 male and 570 female pharmacists. Regarding the highest level of education, $36.8 \%$ of the survey respondents had only Bachelor's degree, 31.8\% had Master's degree or an equivalent Degree as American board, 17.8\% obtained Pharm. D degree, 2.8\% got their Ph.D, and 5\% were still students. The median years of experience were 6 years (IQR: 2-13 years) (Table 1).

The respondents belonged to different specialties: clinical pharmacists $(30.9 \%)$, community pharmacists $(26.5 \%)$, inpatient hospital pharmacists $(13.3 \%)$, outpatient hospital pharmacists $(11 \%)$, drug information pharmacists $(1.7 \%)$, healthcare quality specialists $(0.6 \%)$ and other specialities (Table 2 ). The questionnaire inquired about the general characteristics of the "great pharmacist", including the age, level of education, continuous medical education (CME), specialization, and definition of success. Approximately one third of the respondents chose the age " $30-35$ years" as ideal, while $28.2 \%$ were not able to define a specific age range. Approximately $(64.8 \%)$ of the respondents stated that a postgraduate degree is essential for the great pharmacist, while Pharm.D was chosen by $28.7 \%$ and only $8.8 \%$ saw that a bachelor' degree would suffice. Attendance of the great pharmacist for CME sessions was selected by $33.7 \%$ of respondents to be monthly and $24.9 \%$ to be quarterly. About $60 \%$ of respondents favored specialized expertise over generalized expertise across several pharmacy-related areas. The success of the great pharmacist was defined by high reputation according to $67.4 \%$ of respondents, whereas high position and high salary were selected as success measures by $26 \%$ and $6.6 \%$, respectively (Table 3 ). Moreover, most participants agreed (73\%) for importance of clinical practice to advance the profession and enhance patient care. Also 86.7\% of them agreed for the importance of patient counseling skills. Moreover, most participants $(86.2 \%)$ agreed that the great pharmacist in charge should help the staff learn from their mistakes (Table 4). Approximately (65\%) of the respondents favored formal dealing with other staff, whereas $16 \%$ only favored informal dealing and 19\% were not able to specify (Figure 1). The questionnaire gathered the opinions about skills such as analytical, computer, communication, managerial, and medical research skills. As for leadership skills and mentorship, $75.1 \%$ and $74.5 \%$ agreed for its importance respectively. The survey results indicated that $84 \%$ of pharmacists agreed that leader pharmacists should possess analytical skills, while $5 \%$ disagreed. For computer skills, $91.2 \%$ agreed for having good computer skills while

\begin{tabular}{|c|c|c|c|}
\hline \multicolumn{2}{|c|}{$\begin{array}{l}\text { Table 1: Residence, gender, and } \\
\text { qualifications of the respondents. }\end{array}$} & \multicolumn{2}{|c|}{$\mathbf{N}=905$} \\
\hline \multirow{18}{*}{$\begin{array}{l}\text { In what country do you } \\
\text { currently reside? }\end{array}$} & Egypt & 384 & $42.4 \%$ \\
\hline & Saudi Arabia & 326 & $36.0 \%$ \\
\hline & United Arab Emirates & 75 & $8.3 \%$ \\
\hline & Qatar & 20 & $2.2 \%$ \\
\hline & Jordan & 15 & $1.7 \%$ \\
\hline & Iraq & 15 & $1.7 \%$ \\
\hline & Sudan & 10 & $1.1 \%$ \\
\hline & Kuwait & 10 & $1.1 \%$ \\
\hline & Yemen & 5 & $0.6 \%$ \\
\hline & Turkey & 5 & $0.6 \%$ \\
\hline & Syria & 5 & $0.6 \%$ \\
\hline & Switzerland & 5 & $0.6 \%$ \\
\hline & Palestine & 5 & $0.6 \%$ \\
\hline & North Cyprus & 5 & $0.6 \%$ \\
\hline & Nigeria & 5 & $0.6 \%$ \\
\hline & India & 5 & $0.6 \%$ \\
\hline & Germany & 5 & $0.6 \%$ \\
\hline & Algeria & 5 & $0.6 \%$ \\
\hline \multirow[t]{2}{*}{ What is your Gender? } & Female & 570 & $63.3 \%$ \\
\hline & Male & 330 & $36.7 \%$ \\
\hline \multirow{6}{*}{$\begin{array}{l}\text { What is the highest } \\
\text { level of education you } \\
\text { have completed? }\end{array}$} & Bachelor & 331 & $36.8 \%$ \\
\hline & Diploma & 60 & $7.0 \%$ \\
\hline & Pharm D & 160 & $17.8 \%$ \\
\hline & $\begin{array}{l}\text { Master/or Equivalent Degree/ or } \\
\text { American Board }\end{array}$ & 285 & $31.8 \%$ \\
\hline & Ph. D. & 25 & $2.8 \%$ \\
\hline & Still student & 45 & $5.0 \%$ \\
\hline \multirow{4}{*}{$\begin{array}{l}\text { How many years of } \\
\text { experience? }\end{array}$} & Minimum & 0 & \\
\hline & Maximum & 57 & \\
\hline & Median & 6 & \\
\hline & IQR & $2-13$ & \\
\hline
\end{tabular}

\begin{tabular}{|l|l|l|l|}
\hline $\begin{array}{l}\text { Table 2: Specialization of the survey } \\
\text { respondents. }\end{array}$ & $\mathbf{N}=\mathbf{9 0 5}$ & $\mathbf{\%}$ \\
\hline $\begin{array}{l}\text { What is your } \\
\text { pharmacy } \\
\text { profession? }\end{array}$ & Clinical Pharmacist & 280 & $30.9 \%$ \\
\cline { 2 - 4 } & Community Pharmacist & 240 & $26.5 \%$ \\
\cline { 2 - 4 } & Hospital Pharmacist (Inpatient) & 120 & $13.3 \%$ \\
\cline { 2 - 4 } & Hospital Pharmacist (Outpatient) & 100 & $11.0 \%$ \\
\cline { 2 - 4 } & Pharmacist Intern & 20 & $2.3 \%$ \\
\hline & Student & 15 & $1.7 \%$ \\
\hline & Drug information pharmaci st & 15 & $1.7 \%$ \\
\cline { 2 - 4 } & Not working & 20 & $2.2 \%$ \\
\cline { 2 - 4 } & $\begin{array}{l}\text { Academic and research studies, } \\
\text { college training supervisor }\end{array}$ & 15 & $1.7 \%$ \\
\cline { 2 - 4 } & Quality Control Specialist & 5 & $0.6 \%$ \\
\hline & $\begin{array}{l}\text { Public Health (Supply Chain } \\
\text { Management) }\end{array}$ & 5 & $0.6 \%$ \\
\cline { 2 - 4 } & Physician & 5 & $0.6 \%$ \\
\hline & $\begin{array}{l}\text { Pharmacist working at } \\
\text { Governmental Authority }\end{array}$ & 5 & $0.6 \%$ \\
\hline Inspector & 5 & $0.6 \%$ \\
\hline Industrial pharmacist & 5 & $0.6 \%$ \\
\hline Hospital Supervisor & 25 & $30.0 \%$ \\
\hline Forensic pharmacist & 5 & $0.6 \%$ \\
\hline Drug Store Distribution Pharmacist & 5 & $0.6 \%$ \\
\hline Director of Polyclinics & 5 & $0.6 \%$ \\
\hline Ambulatory care pharmacist & 5 & $0.6 \%$ \\
\hline & &
\end{tabular}




\begin{tabular}{|c|c|c|c|}
\hline \multicolumn{2}{|c|}{$\begin{array}{l}\text { Table } 3 \text { : Age, education, specialization, } \\
\text { and success of the great pharmacist } \\
\text { according to respondents }\end{array}$} & \multirow{2}{*}{$\begin{array}{l}\mathbf{N}=905 \\
135\end{array}$} & \multirow{2}{*}{$\begin{array}{l}\% \\
14.9 \% \\
\end{array}$} \\
\hline \multirow{7}{*}{$\begin{array}{l}\text { In your opinion, what is the Great } \\
\text { pharmacist age? }\end{array}$} & $25-30$ & & \\
\hline & $30-35$ & 285 & $31.5 \%$ \\
\hline & $35-40$ & 165 & $18.2 \%$ \\
\hline & $40-50$ & 35 & $3.9 \%$ \\
\hline & $50-60$ & 15 & $1.7 \%$ \\
\hline & More Than 60 & 15 & $1.7 \%$ \\
\hline & $\begin{array}{l}\text { Does Not Apply or } \\
\text { Don't Know }\end{array}$ & 255 & $28.2 \%$ \\
\hline \multirow[t]{7}{*}{$\begin{array}{l}\text { To what extent do you see the Great } \\
\text { pharmacist level of education? }\end{array}$} & $\begin{array}{l}\text { Master/or } \\
\text { Equivalent Degree/ } \\
\text { or American Board }\end{array}$ & 340 & $37.6 \%$ \\
\hline & Pharm D & 260 & $28.7 \%$ \\
\hline & Ph.D. & 150 & $16.6 \%$ \\
\hline & Bachelor & 80 & $8.8 \%$ \\
\hline & Residency & 5 & $0.6 \%$ \\
\hline & $\begin{array}{l}\text { Not related to } \\
\text { specific formal } \\
\text { education level }\end{array}$ & 39 & $4.3 \%$ \\
\hline & $\begin{array}{l}\text { A pharmacist who } \\
\text { always updates his } \\
\text { information }\end{array}$ & 31 & $3.4 \%$ \\
\hline \multirow{6}{*}{$\begin{array}{l}\text { How often should the ideal Great } \\
\text { pharmacist attend medical sessions } \\
\text { as continuous medical education? }\end{array}$} & Weekly & 155 & $17.1 \%$ \\
\hline & Every 2 weeks & 55 & $6.1 \%$ \\
\hline & Monthly & 305 & $33.7 \%$ \\
\hline & Quarterly & 225 & $24.9 \%$ \\
\hline & Semi Annually & 95 & $10.5 \%$ \\
\hline & Annually & 70 & $7.7 \%$ \\
\hline \multirow{2}{*}{$\begin{array}{l}\text { Should an ideal great pharmacist } \\
\text { have "generalized" expertise across } \\
\text { several pharmacy-related areas or } \\
\text { be "specialized" in specific area of } \\
\text { practice? }\end{array}$} & Specialized & 547 & $60.4 \%$ \\
\hline & Generalized & 358 & $39.6 \%$ \\
\hline \multirow{3}{*}{$\begin{array}{l}\text { How do you define and measure the } \\
\text { Great pharmacist 's success? }\end{array}$} & High Reputation & 610 & $67.4 \%$ \\
\hline & High Position & 235 & $26.0 \%$ \\
\hline & High Salary & 60 & $6.6 \%$ \\
\hline
\end{tabular}

$3.4 \%$ disagreed. In addition, the ability to communicate effectively is an essential skill for an ideal leader; the findings show that $92.2 \%$ agreed for that, and only $4.4 \%$ disagreed. Moreover, $76.8 \%$ agreed that seniors with good managerial skills are great leaders, however, 5.5\% disagreed and 16\% has neutral opinion. For research, $91.7 \%$ of pharmacists agreed for medical research skills, while only $3.9 \%$ disagreed (Table 5). Regarding the ability to manage and discuss mistakes and to solve medical related problems. Firstly, $73.5 \%$ of the respondents highly agreed that the ideal great pharmacist can manage mistakes, while $19.9 \%$ moderately agreed and $6.7 \%$ did not know or agreed to a lesser extent. Secondly, $68 \%$ of the pharmacists highly agreed that to discuss mistakes is a skill for leaders, $28.7 \%$ moderately agreed and $3.3 \%$ did not know or agreed to a lesser extent. While solving any medication-related problems, $84 \%$ of respondents highly greed, $13.3 \%$ moderately agreed, $2.8 \%$ did not know or agreed lesser extent (Table 6).

\section{DISCUSSION}

Using the FADIC Pharmacy Practice listserver was determined to be effective way to contact health-system pharmacists for participation in this survey research. ${ }^{[5]}$ While the response rate for this survey was low, it was comparable to that of previous research on this subject and provides valuable insight about

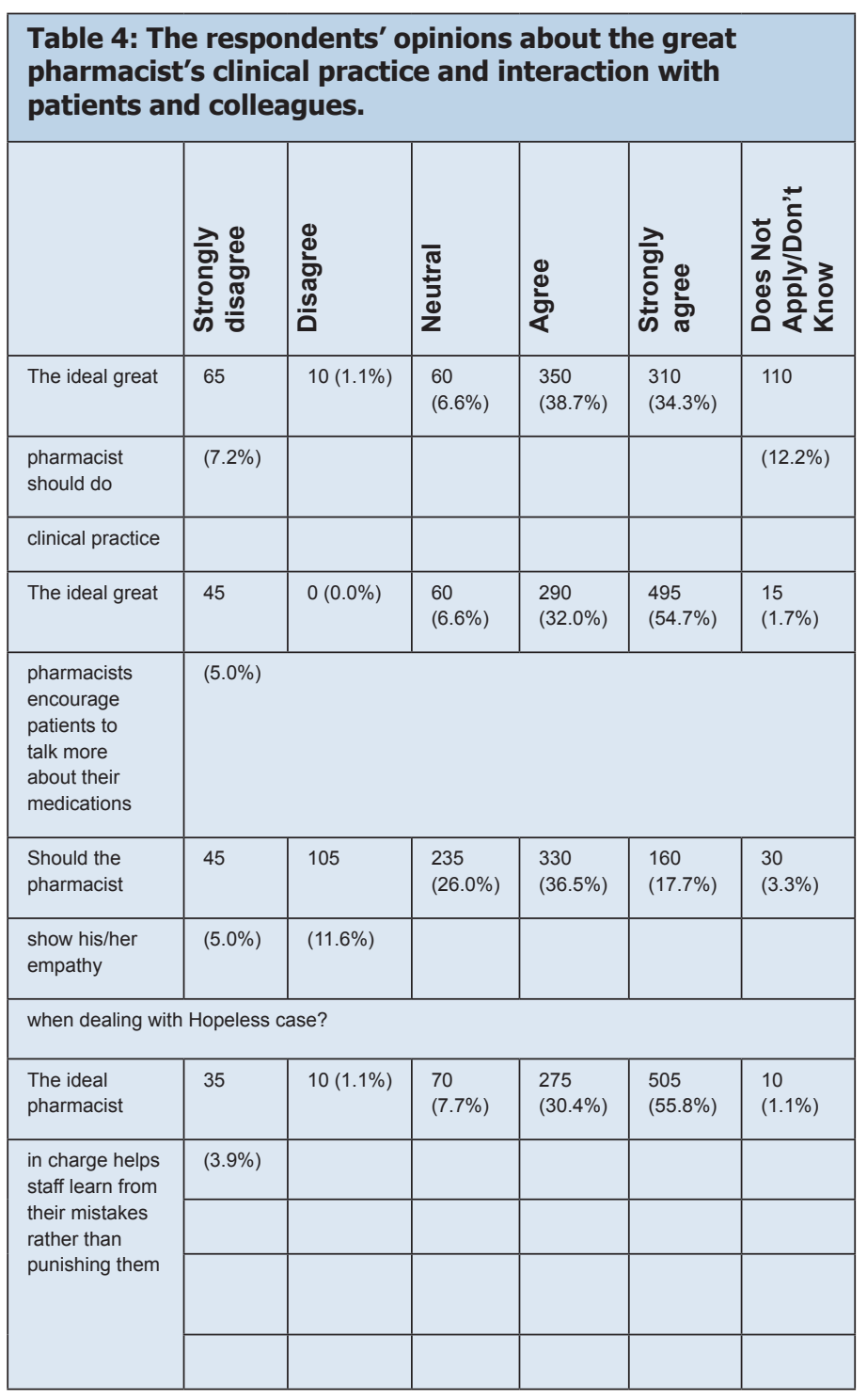

the opinion of pharmacists as regards the great pharmacist's characteristics, and the factors that help a pharmacist to make a leap. ${ }^{[5]}$

In general, the concept of good to great is very good. The core idea is about acquiring important skills needed for the pharmacists as leaders. ${ }^{[6,7]}$ Additionally, there is a need to be successful not only for smaller goals (i.e., individual interests), but also larger scale of goals (i.e., organizations), as Jim Collins stated that leadership is one among the key variables of the successfulness of organizations. ${ }^{[8]}$ He has shown us how good to great companies gain their success under their great leaders and those succeeding after them. ${ }^{[9]}$ This study shows the importance of the leadership characteristics. ${ }^{[10]}$ These data are useful in that they provide the pathways that pharmacy leaders took, report the skill sets these leaders value most, confirm the pipeline for future health-system pharmacy directors, and provide the employing preferences of current health-system pharmacy directors. ${ }^{[1]}$ The idea of Good to Great is not only based on theoretical analysis but also comes from practical data taken from various experiences of pharmacists. ${ }^{[12]}$ The combination between theory analysis and practical data has given this survey a strong basic assumption of the validity of Good to Great theory. ${ }^{[13]}$ Respondents to this opinion survey worked in the medication management and use, as 740/905 respondents are among clinical, hospital, and community 
Elshenawy and Mahmoud.: Study about Qualifications and Skills Required for Ideal Great Pharmacist

Table 5: The respondents' opinions about the skills that should be possessed by the great Pharmacist.

\begin{tabular}{|l|l|l|l|l|l|l|}
\hline & $\begin{array}{l}\text { Strongly } \\
\text { disagree }\end{array}$ & Disagree & Neutral & Agree & $\begin{array}{l}\text { Strongly } \\
\text { agree }\end{array}$ & $\begin{array}{l}\text { Does Not Applyl } \\
\text { Don't Know }\end{array}$ \\
\hline Should the ideal & 10 & $55(6.1 \%)$ & $150(16.6 \%)$ & 395 & $285(31.5 \%)$ & $10(1.1 \%)$ \\
\hline pharmacist be a leader? & $(1.1 \%)$ & & & $(43.6 \%)$ & & \\
\hline Should the ideal & 25 & $30(3.3 \%)$ & $125(13.8 \%)$ & 385 & $290(32.0 \%)$ & $50(5.5 \%)$ \\
\hline $\begin{array}{l}\text { pharmacist be a } \\
\text { mentor? }\end{array}$ & $(2.8 \%)$ & & & $(42.5 \%)$ & & \\
\hline Should a great & 20 & $25(2.8 \%)$ & $95(10.5 \%)$ & 390 & $370(40.9 \%)$ & $5(0.6 \%)$ \\
\hline $\begin{array}{l}\text { pharmacist have good } \\
\text { analytical } \\
\text { skills? }\end{array}$ & $(2.2 \%)$ & & & $(43.1 \%)$ & & \\
\hline Should Great & 15 & $15(1.7 \%)$ & $45(5.0 \%)$ & 455 & $370(40.9 \%)$ & $5(0.6 \%)$ \\
\hline $\begin{array}{l}\text { pharmacist have good } \\
\text { computer skills? }\end{array}$ & $(1.7 \%)$ & & & $(50.3 \%)$ & & \\
\hline Should Great & 20 & $30(3.3 \%)$ & $145(16.0 \%)$ & 415 & $280(30.9 \%)$ & $15(1.7 \%)$ \\
\hline $\begin{array}{l}\text { pharmacist have good } \\
\text { managerial skills? }\end{array}$ & $(2.2 \%)$ & & & $(45.9 \%)$ & & \\
\hline Should Great & 25 & $10(1.1 \%)$ & $30(3.3 \%)$ & 355 & $475(52.5 \%)$ & $10(1.1 \%)$ \\
\hline $\begin{array}{l}\text { pharmacist have good } \\
\text { medical research skills? }\end{array}$ & $(2.8 \%)$ & & & $(39.2 \%)$ & & \\
\hline $\begin{array}{l}\text { Should Great } \\
\text { pharmacist have good } \\
\text { communication skills? }\end{array}$ & 40 & $0(0.0 \%)$ & $25(2.8 \%)$ & 195 & $640(70.7 \%)$ & $5(0.6 \%)$ \\
\hline
\end{tabular}

pharmacists. ${ }^{[14]}$ The results indicate that there is a pipeline of pharmacists who are interested to be effective and great members in the pharmacy practice. ${ }^{[15]}$

Among the results from this survey, the qualification of the ideal pharmacist should be complemented by post graduate certification, such as master's degree, Board of Pharmacy Specialties' (BPS), or Ph.D. degree. While the past Survey of health-system pharmacy leadership pathways recommend that the on-the-job experience was identified as the most common leadership pathway. ${ }^{[3]}$ The most valued skills to the great pharmacist were analytical skills, computer skills, managerial skills, clinical research skills and the good communication skills. ${ }^{[16]}$ However, in the study of the health-system pharmacy leadership pathways, the medication-use policy, human resource management, and interpersonal skills were identified as the most valued skill sets. ${ }^{[17]}$ This is pertinent information to consider when interpreting results that combined the responses of leaders who completed post graduate studies with the responses of leaders who have leadership skills. Most respondents had been in their position for 5 years or less. Supporting the claim that this can be attributed to the number of pharmacy leaders who frequently changed jobs, ${ }^{[18]}$ the majority of our respondents stated that they held more jobs in their career with a median tenure of 6 years. Also similar to the results of the survey by Sacha R. Pollard and John S. Clark, the majority of our respondents stated that the leadership feature is one of the important characters needed for the great pharmacists. ${ }^{[19]}$

The management skills were selected as one of the important skill. Our study group determined that a candidate with experience would be desired if ability to perform was unaffected by education or training. ${ }^{[2]}$ As more pharmacists receive structured training, there is an anticipated shift in directors who will seek to hire leaders with this training, with respect to the past experience. ${ }^{[20]}$

There are some additional characteristics of the great pharmacists such as

\section{Table 6: The respondents' opinions about management of mistakes and Medication-related problems by the great pharmacist.}

\begin{tabular}{|l|l|l|l|l|}
\hline & High & Moderate & Low & $\begin{array}{l}\text { Don't } \\
\text { Know }\end{array}$ \\
\hline To what extent do you & $\begin{array}{l}665 \\
(73.5 \%)\end{array}$ & $180(19.9 \%)$ & 35 & $25(2.8 \%)$ \\
\hline $\begin{array}{l}\text { think the ideal Great } \\
\text { pharmacist can manage } \\
\text { mistakes? }\end{array}$ & $\begin{array}{l}615 \\
(68.0 \%)\end{array}$ & $260(28.7 \%)$ & 10 & $20(2.2 \%)$ \\
\hline $\begin{array}{l}\text { To what extent do you see } \\
\text { discuss mistakes? }\end{array}$ & $\begin{array}{l}(8.9 \%) \\
\text { the ideal Great pharmacist } \\
\text { (8.0\%) }\end{array}$ & $120(13.3 \%)$ & 15 & $10(1.1 \%)$ \\
\hline $\begin{array}{l}\text { To what extent do you see } \\
\text { polving medication-related } \\
\text { problems? }\end{array}$ & & & $(1.1 \%)$ & \\
\hline
\end{tabular}

interpersonal skills, accuracy, integrity, ability to multitask, diplomacy, ability to priorities, counseling, mentoring, and being updated. ${ }^{[21]}$

A limitation of this survey research is that it only sampled members of the FADIC pharmacy practice list server. This list server is not inclusive of all health-system pharmacy leaders, and not all members belonging to the list server had active e-mail addresses on file at the time of survey recruitment. ${ }^{[22]}$ The majority of survey responders were trained through 


\section{Elshenawy and Mahmoud.: Study about Qualifications and Skills Required for Ideal Great Pharmacist}

on-the-job experience in the middle east. ${ }^{[1]}$ An additional limitation was that respondents had 6 to 13 years of experience; therefore, these respondents may have been less likely to report the benefits of this experience. ${ }^{[23]}$ This is pertinent information to consider when interpreting results that combined the responses of pharmacists who completed the responses of the study. ${ }^{[24]}$

According to the American Society of Health-System Pharmacists practical model, ${ }^{[2]}$ in order to determine how innovative roles can be integrated into an institution's pharmacy practice model, ${ }^{[25]}$ it is imperative to understand the further skills needed to the ideal great pharmacists. ${ }^{[26]}$ This is essential to achieve the transition from good to great ones that require further studies. ${ }^{[27]}$

\section{CONCLUSION}

This study demonstrated that there are many qualifications to be an ideal pharmacist. A leader pharmacist is the one who use his skills to enhance his confidence and professional efficiency. Moreover, we recommend further follow-up and research for exploring more about how to be an Ideal pharmacist. It is crucial that the ideal great pharmacists in clinical practice involvement; thus, each of their roles includes a staffing component, which enables ongoing refinement of clinical research and affords an ideal opportunity to sustain mentorship and leadership. Overall, these innovative positions have streamlined pharmacy processes and provided the solid management structure needed to support the department's critical tasks and responsibilities.

\section{Author contributions}

The authors developed the concept and methodology for the review and undertook data extraction and reviewing. Additionally, drafted the initial manuscript. All authors contributed significantly to data interpretation and contributed significantly to the revision of the manuscript and finalization for submission.

\section{ACKNOWLEDGEMENT}

The authors thank pharmacist respondents and members of FADIC who participated in the study. The authors also acknowledge the FADIC administrative team that help in distribution of the survey among pharmacists. The datasets used and/or analyzed during the current study are available from the corresponding author on reasonable request where not presented in the manuscript or Figure.

\section{CONFLICT OF INTEREST}

All other authors declare no potential conflict of interest.

\section{ABBREVIATIONS}

SPSS: Statistical Package for Social Sciences; IQR: interquartile range; BPS: Board of Pharmacy Specialties.

\section{REFERENCES}

1. Al Aqeel S, Abanmy N, AlShaya H, Almeshari A. Interventions for improving pharmacist- led patient counselling in the community setting: A systematic review. Syst Rev. 2018;7(1):71. doi: 10.1186/s13643-018-0727-4, PMID 29720247.

2. Developed through the ASHP Section of Inpatient Care Practitioners Section Advisory Group on Medication Safety and approved by the ASHP Council on Education and Workforce Development on February 21, 2012; by the ASHP Board of Directors on April 13, 2012; ASHP statement on the role of the medication safety leader. Am J Health Syst Pharm. 2013;70(5):448-552. doi: 10.2146/sp120010. PMID 23413170.

3. Anderson HD, Saseen JJ. The importance of clinical research skills according to PharmD students, first-year residents, and residency directors. Curr Pharm
Teach Learn. 2017;9(2):224-9. doi: 10.1016/j.cptl.2016.11.011, PMID 29233407.

4. Axworthy S, Mackinnon NJ. Perceived importance and self-assessment of the skills of Canada's health-system pharmacy managers. Am J Health Syst Pharm. 2002;59(11):1090-7. doi: 10.1093/ajhp/59.11.1090, PMID 12063895.

5. Feller TT, Doucette WR, Witry MJ. Assessing opportunities for student pharmacist leadership development at schools of pharmacy in the United States. Am J Pharm Educ. 2016;80(5):79. doi: 10.5688/ajpe80579, PMID 27402982.

6. Fuller PD. Program for developing leadership in pharmacy residents. Am J Health Syst Pharm. 2012;69(14):1231-3. doi: 10.2146/ajhp110639, PMID 22761078.

7. Gelayee DA, Mekonnen GB, Birarra MK. Involvement of community pharmacists in continuing professional development (CPD): A baseline survey in Gondar, Northwest Ethiopia. Global Health. 2018;14(1):15. doi: 10.1186/s12992-0180334-0, PMID 29391021.

8. Hertig JB, Radman D, Sisodiya D, Dabestani A. Creating innovative leadership roles to improve pharmacy practice. Am J Health Syst Pharm. 2013;70(4):306-7, 309. doi: 10.2146/ajhp120340, PMID 23370137.

9. IBM; 2017. IBM SPSS Statistics for windows, Version 25. Armonk NY. IBM Corp. Available from: http://www-01.ibm.com/support/docview.wss?uid=swg27049428 [cited 20/7/2021].

10. Ishizaki J. Improvement of clinical skills through pharmaceutical education and clinical research. Yakugaku Zasshi. 2017;137(1):9-12. doi: 10.1248/ yakushi.16-00220-2, PMID 28049901.

11. Janke KK, Tofade T. Making a curricular commitment to continuing professional development in doctor of pharmacy programs. Am J Pharm Educ. 2015;79(8):112. doi: 10.5688/ajpe798112, PMID 26692371.

12. McConnell KJ, Newlon CL, Delate T. The impact of continuing professional development versus traditional continuing pharmacy education on pharmacy practice. Ann Pharmacother. 2010;44(10):1585-95. doi: 10.1345/aph.1P161, PMID 20841517.

13. Meadows AB, Maine LL, Keyes EK, Pearson K, Finstuen K. Pharmacy executive leadership issues and associated skills, knowledge, and abilities. J Am Pharm Assoc (2003). 2005;45(1):55-62. doi: 10.1331/1544345052843183, PMID 15730118.

14. O'Connor M, Weber RJ. Issues facing pharmacy leaders in 2013. Hosp Pharm. 2013;48(5):433-7. doi: 10.1310/hpj4805-433, PMID 24421500.

15. Obreli-Neto PR, Marques Dos Reis TM, Guidoni CM, Girotto E, Guerra ML, de Oliveira Baldoni A, Leira Pereira LR. A systematic review of the effects of continuing education programs on providing clinical community pharmacy services. Am J Pharm Educ. 2016;80(5):88. doi: 10.5688/ajpe80588, PMID 27402991.

16. Patterson BJ, Chang EH, Witry MJ, Garza OW, Trewet CB. Pilot evaluation of a continuing professional development tool for developing leadership skills. Res Social Adm Pharm. 2013;9(2):222-9. doi: 10.1016/j.sapharm.2012.04.006, PMID 22695217.

17. Pollard SR, Clark JS. Survey of health-system pharmacy leadership pathways. Am J Health Syst Pharm. 2009;66(10):947-52. doi: 10.2146/ajhp080186, PMID 19420312.

18. Poudel RS, Piryani RM, Shrestha S, Chaurasiya R, Niure BP. Opinion of hospital pharmacy practitioners toward the Continuing Pharmacy Education program: a study from a tertiary care hospital in central Nepal. Integr Pharm Res Pract. 2017;6:157-61. doi: 10.2147/IPRP.S145026, PMID 29354562.

19. Collins J, Zaenuddin Hudi Prasojo Rb. GOOD TO GREAT: WHY SOME COMPANIES MAKE THE LEAP...AND SOME OTHERS DON'T. al-albab;1(1). doi: 10.24260/alalbab.v1i1.18.

20. Smith LC, Patel RJ, Kurz D, Kroner BA. Perceived value of leadership experiences in a postgraduate year 2 ambulatory care pharmacy residency. Am J Health Syst Pharm. 2018;75(23);Suppl 4:S101-7. doi: 10.2146/ajhp170544, PMID 30333112.

21. Tofade $T$, Duggan $C$, Rouse $M$, Anderson $C$. The responsibility of advancing continuing professional development and continuing education globally. Am J Pharm Educ. 2015;79(2):16. doi: 10.5688/ajpe79216, PMID 25861097.

22. Urteaga EM, Attridge RL, Tovar JM, Witte AP. Evaluation of clinical and communication skills of pharmacy students and pharmacists with an objective structured clinical examination. Am J Pharm Educ. 2015;79(8):122. doi: 10.5688/ ajpe798122, PMID 26690286.

23. Vlasses PH, Wadelin JW, Boyer JG, Travlos DV, Rouse MJ, Avery C. 2016 Annual report of the Accreditation Council for Pharmacy Education. Am J Pharm Educ. 2017;81(7):S9. doi: 10.5688/ajpe817S9, PMID 29109573. 
Elshenawy and Mahmoud.: Study about Qualifications and Skills Required for Ideal Great Pharmacist

24. Wheeler JS, Chisholm-Burns M. The benefit of continuing professional development for continuing pharmacy education. Am J Pharm Educ. 2018;82(3):6461. doi: 10.5688/ajpe6461, PMID 29692444.

25. White SJ, Enright SM. Is there still a pharmacy leadership crisis? A seven-year follow-up assessment. Am J Health Syst Pharm. 2013;70(5):443-7. doi: 10.2146/ ajhp120258, PMID 23413169.
26. Wilbur K. Pharmacist continuing education degree program. 2016;1:1-6.

27. Wolf M, Smith J, Proctor C. Pharmacy leadership development through national resident collaboration. Am J Health Syst Pharm. 2016;73(5):268-9. doi: 10.2146/ ajhp130778, PMID 26896496.

Cite this article as: Elshenawy RA, Mahmoud FA. Why some Pharmacists Make the Leap and Others do not "From Good to Great Pharmacists".. J Pharm Pract Community Med. 2021;7(2):28-33. 